\title{
MORE MONEY, MORE AUTONOMY?: WOMEN AND CREDIT IN A JAVANESE URBAN COMMUNITY'
}

\section{Hotze Lont}

Author's Note: This essay is based on fieldwork conducted in Bujung between October 1997 and August 1998, later followed by a shorter visit in July and August 1999. The research area can be roughly divided into a wealthier upper section and a relatively poor lower section. During most of the term of my fieldwork I lived in the upper section of the ward, where I rented a house with a former head of the neighborhood. I tried to participate in daily life as much as possible, so that I was able to observe daily activities and social interaction, engage in informal conversations with a wide variety of people, and eavesdrop on all kinds of gossip. In the meantime, I conducted a large number of more or less structured interviews with both women and men. To gather more quantitative data, I organized a structured questionnaire distributed among 156 households, while at the same time I found ten women prepared to fill in booklets with daily income and expenditures for two separate months.

The issues examined in this paper were not easy to investigate. I believe that there is hardly any society where people will easily discuss their financial problems and strategies openly with relative strangers, but in Javanese society there is a particularly strong taboo against open discussion or acknowledgment of debts. As an example: although every day a number of moneylenders traversed the ward, hardly anybody was willing to admit that he or she borrowed money from them, but at the same time many people were quickly willing to say

\footnotetext{
${ }^{1}$ I am grateful to Frans Hüsken and Gerben Nooteboom for the helpful comments I received from them while writing this article. This research is sponsored by the Royal Netherlands Academy of Arts and Sciences (KNAW).
} 
that all their neighbors did. The fact that people were willing to gossip about the loans of others, but not willing to discuss their own loans in earnest, presented a big problem, something which could only be solved by close and frequent observation and by gaining the confidence of a small number of key informants.

Another initial problem was the fact that it was not a simple matter for me, as a male researcher, to interview women. In the first months, I was usually more or less forced to conduct interviews with the husband, with his wife as a silent witness. He would normally answer the questions, often incorrectly, even though they clearly related to the competency of his wife. Only after I had completed about half of my fieldwork did it become possible to interview women on their own, although this was clearly less problematic in the lower section than in the upper section of the ward. It was easier to approach the women living in Bujung's lower section, where they spent more time outside the house because their kitchens were too small for simultaneous cooking and laundering. What's more, their lower status within the community perhaps allowed them to bypass or ignore general rules of conduct more often. ${ }^{2}$

On a sunny afternoon in July, I meet Parman in a foodstall on the main road close to his home. Parman is a coolie whom I have come to know very well. He has just gotten a ride with a truck that had come to Yogyakarta to deliver building material and needed help unloading, a job that earned him Rp4,500. Now he is tired and hungry. Parman orders a large plate of rice and vegetables, together with tea and some snacks, and after the meal he buys a cigarette. For this food and for the breakfast, which he had taken in the morning, he has to pay Rp4,000.

Then I offer Parman a ride to his house, and so we leave. At his house, his wife is waiting, he tells about his job and orders her to fix a cup of tea for the guest. She prepares the drink and asks her husband for the money he earned. Parman throws a wrinkled Rp500 note down in front of her. Her face turns gray and she grimaces. For a moment it is unclear whether she wants to rail at him or cry. In the end she just mumbles: "Is that all!?"

This incident may appear to feature a defenseless housewife waiting at home for what money her husband is willing to give her. In fact, Parman's wife is not so passive or entirely defenseless as that image suggests. She holds two jobs herself, working in the morning and the evening, but that income is not enough to support her family. She therefore remains dependent on the highly uncertain income of her husband. This is just one of many examples I encountered illustrating the tensions that exist between husbands and wives in Bujung, the ward where I conducted my fieldwork. Judging from my observations, a large percentage of the conflicts between spouses is related to money issues.

The incident involving Parman and his wife relates directly to an ongoing debate between social anthropologists working in Southeast Asia, a debate which focuses on the position of women in the household, her status, power, and room for maneuvering

2 See also Ward Keeler, "Speaking of Gender in Java," in Power and Difference: Gender in Island Southeast Asia, ed. Jane M. Atkinson and Shelly Errington (Stanford: Stanford University Press, 1990). 
vis-à-vis her husband. In this debate, many scholars have accepted the notion that women in Southeast Asia enjoy particularly strong decision-making power within the household. It is often noted that Javanese women have no cultural restrictions on their mobility in the sense that they are free to venture out of the house independently, and so they have ample opportunities to work and earn an income. These factors, it is assumed, ensure that Javanese women wield most, or all, of the decision-making power over the household budget. ${ }^{3}$

Other scholars have challenged some of these assumptions and offered more balanced assessments of women's roles in Southeast Asia. Hildred Geertz, for example, observes that differences exist between one household and the other, though she goes on to argue that the balance of power usually favors the wife: "household management ranges from dominance by the wife to a point of almost complete equality." 4 Ward Keeler also makes clear that the decision-making power of women is sometimes restricted, especially when it comes to large expenditures. ${ }^{5}$ Hanna Papanek and Laurel K. Schwede present relevant quantitative figures from urban Jakarta. Their data confirm the traditional opinion, showing that in two out of three households the wife is dominant with regard to financial decision-making; in one in five households, decisions are reached jointly; and in only one in twenty households is the husband dominant. ${ }^{6}$ Wolf, however, criticizes these research findings and argues that answers to any question about the roles of women can be considerably different if the question is asked in a more direct and less abstract way. ${ }^{7}$ In that case it becomes clear, according to Wolf, that contrary to the general norm, the husbands are the ones who most often decide on expenditures. Wolf also emphasizes that a strong economic position is not consistently accompanied by equally strong cultural prestige; Keeler makes a similar argument. ${ }^{8}$ Handling money, taking loans, and negotiating small money exchanges at the market are not highly valued activities in the Javanese cultural context. Therefore, when women in Java are given space as economic actors, this, in fact, signifies an inferior social position. ${ }^{9}$ Some of the controversies in this debate can be accommodated and issues clarified by taking into account the distinction between the interrelated concepts of "female autonomy" and "social power," as Ann Stoler has

\footnotetext{
3 See Robert R. Jay, Javanese Villagers: Social Relations in Rural Modjokuto (Cambridge, MA: MIT Press, 1969), pp. 92-3; and Lenore Manderson, "Introduction," in Women's Work and Roles: Economics and Everyday Life in Indonesia, Malaysia and Singapore, ed. L. Manderson (Australian National University Development Studies Center, 1983), p. 6.

${ }^{4}$ Hildred Geertz, The Javanese Family: A Study of Kinship and Socialization (Glencoe: Free Press, 1961), p. 125.

${ }^{5}$ Keeler, "Speaking of Gender in Java," p. 129.

6 Hanna Papanek and Laurel K. Schwede, "Women Are Good With Money: Earning and Managing in an Indonesian City," in A Home Divided: Women and Income in the Third World, ed. Daisy Dwyer and Judith Bruce (Stanford, CA: Stanford University Press, 1988), pp. 89-91.

7 Diane L. Wolf, Factory Daughters: Gender, Household Dynamics, and Rural Industrialization in Java (Berkeley: University of California Press, 1992), p. 65.

${ }^{8}$ Keeler, "Speaking of Gender in Java," p. 128.

${ }^{9}$ Wolf, Factory Daughters, p. 66. Suzanne A. Brenner in The Domestication of Desire: Women, Wealth, and Modernity in Java (Princeton: Princeton University Press), pp. 134-70, argues against this, saying that women's involvement in the worldly affairs of money is, in another sense, viewed as a crucially important role, which mediates between acquiring essential resources and upholding the pride of the family.
} 
86 Hotze Lont

proposed. According to Stoler, "female autonomy" refers to "the extent to which women exercise economic control over their own lives vis-à-vis men (e.g., in disposing of the fruits of their labour)" and "social power" refers to the "extent in which women exercise control over the lives of others outside the domestic sphere." 10 This paper concentrates on the financial autonomy of Bujung women, meaning the ability of women to spend money according to their own wishes and insights.

In this paper, I would like to connect the ongoing discussion about the position of women in Indonesia with another discussion, one on credit and microfinance as policy interventions. In the latter sphere, it has often been observed that women have less access to credit than men do, especially when it comes to "formal" sources of credit, such as banks and governmental credit programs. These institutions tend to look for customers only among men, and they require collateral that is often in the hands of men. Among those who have recognized this problem, many have advocated credit programs specially targeted at women, usually with women's "empowerment" as a final objective. Advocates believe that access to credit increase women's independence and improve their position within and outside the household. ${ }^{11}$ Critics of such policies have argued, however, that the idea that credit can create "empowerment" is overly simplistic, and that in many cases the provision of credit (or debt) is worsening the position of women rather than improving it. ${ }^{12}$ The purpose of this paper is to determine whether access to credit has a positive influence on female financial autonomy. The paper focuses on understanding the various ways in which Bujung households operate and how the positions of women differ from one social category to another in order to discover what access to credit means for female autonomy. ${ }^{13}$

\section{Bujung, the Research Area}

Bujung is a ward at the outskirts of the city of Yogyakarta with approximately six thousand inhabitants. The central part of the ward is dominated by the well-cared-for houses of local businessmen, civil servants, and teachers, sharply segregated from the poorer dwellings of laborers and pedicab drivers. The houses of the poorer residents are concentrated on lower ground, on the slopes of the two small rivers that border the ward. The ward is the home of a somewhat fragmented, but close-knit, community where contacts between neighbors are strong and voluntary working projects and funerals are well attended. The inhabitants of Bujung can be divided roughly into three

\footnotetext{
${ }^{10}$ Ann Stoler, "Class Structure and Female Autonomy in Rural Java," Signs 3 (1977): 74-89, esp. 74.

11 See for instance Syed M. Hashemi et al. "Rural Credit Programs and Womer's Empowerment in Bangladesh," World Development 24,4 (1996): 635-53.

12 Aminur Rahman, "Micro-Credit Initiatives for Equitable and Sustainable Development: Who Pays?," World Development, 27,1 (1999): 67-82; Linda Mayoux, "Microfinance and Women's Empowerment Issues," Devfinance (September 15, 1999), available by E-mail: devfinance@lists.acs.ohio-state.edu; Dale W. Adams, "Inflated Expectations," Devfinance (September 27, 1999), available E-mail: devfinance@lists.acs.ohio-state.edu.

13 In the case of Bujung, it is very appropriate to follow the second proposition of Stoler that the question of class relations is analytically prior to the investigation of male-female relationships within classes. See Stoler, "Class Structure and Female Autonomy," p. 75.
} 
different categories: two categories of people with relatively stable incomes and one category of people with relatively unstable incomes.

The first category is made up of the descendants of original families who continue to own large portions of land in the ward. They have sold a large part of what they used to own, but they still derive a significant amount of income from renting houses and rooms to others. Most of them have a junior high school education, and they often run small enterprises or work in the lower ranks of the civil service. The second category includes the richer families of immigrants with office jobs. They usually have a senior high school education or even a university education. Most of them arrived in Bujung shortly after 1965, and they have built houses of good quality on land which they bought from the original inhabitants. ${ }^{14}$ People in these first two categories live in the section of the ward located on higher ground, and they enjoy strong social interactions with each other. In terms of income, their situations are similar. Most of these households depend in large part on the monthly salary of one or more office workers or on the revenues of a well-established enterprise. Although these incomes are too modest to allow them to attain the coveted lifestyle of the upper middle-classcomplete with the car, mobile phone, and satellite dish-the important thing is that they are fairly stable. To supplement this stable basic income, individuals in these families often have access to all kinds of part-time jobs that provide larger or smaller irregular incomes.

The third category is that of the poor migrants living on the slopes of the rivers. Most of these residents came to Bujung in the 1970s from the dry agricultural district of Gunung Kidul, Yogyakarta Province. Few of them have more than an elementary school education. The financial situation of the lower class households in Bujung is significantly different from the situation of the upper class households. They depend heavily on daily incomes, which are intermittent and insecure; earnings from such jobs are cut off when a person is ill or cannot work for any other reason. Typical occupations for men of this class are pedicab driver, coolie, construction worker, or parking guard. Women earn irregular incomes as traders or by producing goods to sell in the home, but a large number of women in this category find regular employment as housemaids or laundry ladies, which earns them a very low but stable monthly income.

\section{Balancing Income and Expenditures in Bujung Households}

While acknowledging that there are many exceptions, one can say that over the past decade the nuclear family has become Indonesia's dominant economic household unit. The majority of households in Bujung consists of two parents and a few, most often two, children. Typical exceptions are households where elderly parents live with their children and grandchildren, or single mothers with one or more children. In a few cases other relatives or friends join the household irregularly, usually for a short

\footnotetext{
14 The year 1965 is a turning point in both national and local history. It was the year of the massive crackdown on the Indonesian Communist Party (PKI), in which hundreds of thousands were killed and which marked the beginning of the New Order regime. Bujung in those days was one of the centers of the communist party in Yogyakarta. Many local leaders were killed or imprisoned, leaving space for others to rise to prominence within the community.
} 
period. ${ }^{15}$ In the households of Bujung, occupational multiplicity is the standard. Not only does the household income come from various household members, but each person usually derives an income from various sources. This way, households experience a complex mix of income cycles, where part of the money may be acquired on a daily basis, another part on a monthly basis, and the rest occasionally and unpredictably. Generally, in most households, the incomes of both partners are substantial, relative to each other, but the husband earns more. ${ }^{16}$ However, in a large number of households, especially among the laborers of the lower section of the ward, the wife earns more than the husband. ${ }^{17}$ In cases where unmarried youngsters earn an income of their own, they are generally free to spend it for themselves. With a few exceptions, they are only asked to contribute to the family when there is a deficiency of household funds.

In the eyes of people in Bujung, a monthly income is most desirable. It provides more security and makes it easier to take care of monthly expenditures, in addition to making a person more eligible for credit. A monthly income is normally associated with civil servants and with employees of private companies, but the many housekeepers and laundry ladies in the ward also receive their wages once a month. The disadvantage of a monthly income is that one has to be very careful with spending, so that one does not have to pass the last days of the month with an empty wallet. ${ }^{18}$ People who receive weekly incomes have similar problems with financial planning. They may also find it more difficult to deal with large expenditures. The weekly income is typical for laborers engaged in small enterprises, such as workshops and retail shops.

But most people in Bujung earn a daily income, which is more or less uncertain for nearly all such workers. Small food traders, home producers, pedicab drivers, construction workers, parking guards, taxi drivers, coolies, scavengers, and shop owners, for example, all rely on daily incomes. These people have to find ways to deal with days when they earn a minimal income or nothing at all. It is very difficult for them to deal with larger expenditures.

When describing income situations in Bujung, one must pay attention to the notion of rezeki, a word that popped up in almost every discussion or interview I conducted

\footnotetext{
15 In the two neighborhood sections where I concentrated my fieldwork, more than half of the households consisted of two parents and one or more children. One in seven households consisted of two parents, one or more children, and one or more grandparents, and one in ten households consisted of a single mother and one or more children. The remaining households fell into different, smaller categories.

16 It proved to be very hard to quantify the size of the contributions of women in these households because there is a strong tendency among both women and men to disqualify the income earning activities of the wife as "just helping the husband" (bantu-bantu suami).

17 When Panut, a pedicab driver, was found guilty of adultery and banned from the neighborhood for three years by a popular tribunal, his wife danced and sang in front of her house. The reason for her display was not so much her husband's promiscuous behavior-she had been aware of that fact for several years-but mainly because Panut was a "pain in the neck" and cost more than he contributed to the household. A neighboring woman said: "He is just lying around each day, only begging for food and money for cigarettes. She is working hard and I really feel pity for her."

18 Wives of civil servants regularly complained that they were stressed during the final days of each month, and a woman who went from house to house in the mornings peddling breakfast snacks told me that her business was significantly diminished at the end of every month.
} 
on income and expenditures. The word rezeki connotes luck and is used to refer to a windfall, a sudden burst of income, relatively large and more or less unexpected. It is a special consequence of the fluctuation of incomes in Bujung. Civil servants regularly receive special bonuses, which they consider rezeki. Pedicab drivers may have many customers on one day, or a single tourist who pays exceptionally well. Coolies may suddenly be hired for a heavy, but well-paying, job. The group of housewives who annually travel to the North Javanese town of Pekalongan to wrap Idul Fitri presents also consider this income as rezeki. And of course winning the lottery is rezeki as well. People in Bujung like to use their rezeki for something special, like buying new clothes or a present for the grandchildren. However, many people are forced to use part of it to repay their debts, as a way to balance financial cycles in the household. Without access to rezeki, few people would dare to take on debts in order to deal with unexpected costs.

The predominant situation in many households, characterized by unreliable cycles of household income, is matched by equally irregular cycles of expenditures. This is not to say that life for such families is entirely chaotic; just as most households rely on certain reliable, basic sources of income, they also must meet certain basic expenditures. Most of the household budget is spent on food. Most families spend fairly consistent amounts of money daily on rice, vegetables, meat or soybean cake, snacks, and sweets. ${ }^{19}$ Other daily purchases might include soap, cigarettes, and school fees for primary school. During longer cycles, people are confronted with other costs. Each month there are the electricity and water bills, monthly fees for high school, and contributions to mutual associations. Each year, the rent has to be paid (if people do not own their house or land), the costs of Idul Fitri (the Islamic feast at the end of the Ramaddan) must be covered, and certain annual school fees come due. On an irregular basis, people are confronted with costs of illness, of family rituals-such as weddings, funerals, or circumcisions-with reciprocal contributions to other households, and housing costs. Patterns of expenditure differ from one household to another depending on luck, wants, and the family cycle. Obviously these costs, whether they are expected or not, do not always tally with income flows. When, for one reason or another, it is not possible or desirable to expend one's own savings or seek financial help from others, the only possible solution is to borrow.

\section{Sources of Credit}

Parker Shipton defines credit or loans as "any transfer of goods or services by one person or group to another, or to any of its members, with the expectation of compensation at a later time." 20 For the people of Bujung, a number of loan options are available, each with its own advantages and disadvantages.

Bank. Only a few people borrow from the bank. The bank requires monthly installments, and late payment is punished with a fine. Interest is set at around 4-5

\footnotetext{
${ }^{19}$ Civil servants and some employees with private firms receive a large bag of rice each month. The quality of this rice is usually bad, and most people try to sell it or mix it with better quality rice.

20 Parker Shipton, "The Rope and the Box: Group Savings in the Gambia," in Informal Finance in LowIncome Countries, ed. Dale W. Adams and Delbert A. Fitchett (Boulder: Westview Press, 1992), p. 27.
} 
percent per month. Civil servants can borrow money at low-interest rates with their income as collateral, but all other people need to have land as collateral, and those who have land often consider the risk of losing their land to be too high. The bank is hardly ever a source of credit that can be used by a woman on her own because the necessary collateral is usually held in her husband's name. In general, the bank is only an option for lower middle-class householders living in the upper section of the ward.

Boss. For those people who work for a boss, the boss figures as one of the most valued sources of credit. This loan option is open to laborers in factories and shops, and to housekeepers and laundry ladies. Most bosses are willing to pay wages in advance, and these loans can be repaid through deductions on future wages, an arrangement that minimizes the risk of default. No interest is charged, and in some cases it is possible for the debtor to renew the loan before it is fully repaid. Some women like to borrow from their bosses, or they may even ask the boss to deduct and hold a portion of their wages in reserve so that they can accumulate a larger fund of shopping money. Similar arrangements exist between traders and suppliers. ${ }^{21}$ Office workers can often borrow from an office co-operative or even from the financial reserves held by their department.

Relatives. Relatives are a problematic source for credit, since usually they only provide big loans in case of urgent needs, and even when such emergencies arise, poor people are still reluctant to go to richer relatives to ask for money. Quite a few stories circulate in Bujung describing how people who have succeeded in life make efforts to avoid contact with their poorer relatives. The main reason for this is probably that loans to kin are usually not repaid, or they are only repaid with thanks, not cash. According to general report, a few lenders in Bujung confronted this problem by demanding that their relatives deliver over the borrower's television set so that they could keep it, as security, until the money was paid back. In most cases, loans from relatives remain limited to small sums lent by siblings who live nearby. If a woman needs just another Rp1,000 to buy vegetables or to pay a moneylender, she will generally approach her sister before asking a neighbor unrelated to her. In general terms, the borrowing conditions that define transactions between relatives resemble those that characterize transactions between neighbors and friends.

Neighbors and friends. In these cases it is also very difficult to deny a person a favor, and in these transactions as well the borrower is very likely to default on the loan. The rule of thumb is that when a person want his or her money to be repaid, he or she must ask for it three times in advance. That way, the borrower is given some time to raise the necessary funds. In some cases people charge interest on loans to their neighbors, but this is not considered a very civil thing to do. These typically small and unsecured loans from relatives, neighbors, and friends are much more common in the lower section than in the upper section of the ward, and although men do make similar arrangements, it is usually women who engage in these types of loans.

21 Traders are often reluctant to ask for such loans from their suppliers, since they are concerned about the negative effects it might have on their business relationship. This is less of an issue when transactions involve laborers and their bosses, although I did come across one case where a laborer was fired because he was taking out too many loans. 
Moneylenders. One of the least appealing options for those who wish to take out a loan is the moneylender. The people in Bujung distinguish between different types of moneylenders. The bank plecit (chasing bank) is a moneylending company from which you can borrow small amounts. It is typically a small company that sends employees to the houses of debtors to collect the daily repayment installments. A second type of moneylender is the rentenir. The rentenir are often single women who live in the ward, give out comparatively large loans, and ask for collateral. Repayment is scheduled on a monthly basis. Some people with whom I spoke distinguished the lintah darat (leech) as a third type of moneylender, similar to the rentenir, except that the lintah darat does not require collateral. These three types of lenders usually charge interest at 20 percent per month. They usually allow a borrower to postpone repayment for some time, though they have been known to grow impatient, enter the debtor's house, and seize assets that more or less represented the value of the debt. A fourth type of lender is called the tukang kredit. As with the bank plecit, the tukang kredit representative goes from house to house. From him you can buy all kinds of things, such as plates, rice cookers, and bicycle tires, and pay them off in daily installments. There is no clearly defined interest rate charged; the interest is included in the prices of the goods.

Both women and men borrow from these moneylenders, although they mainly cater to women because it is more practical for them to deal with people who can be found at home most of the time. The women who reside in the lower section of the neighborhood are most likely to make use of the bank plecit; the bank plecit's daily repayment schedule clearly targets the households of laborers rather than those of office workers. The rentenir and the lintah darat cater to people in the upper area as well as the lower. The work of these moneylenders is comparatively secretive and flexible in accommodating the demands of households depending on monthly incomes.

Shops. Most luxury goods, especially motorcycles, are bought on credit, and many shops in Yogyakarta advertise their willingness to extend credit to customers. But more significant sources of credit are the small food stores, which can be found all over the ward. In many of these shops it is possible to buy food on credit if a person has no money. Shopkeepers expect such debts to be repaid when the customer does have money again, notably on payday. Those who delay repayment will simply never be allowed to borrow again. This practice is called bon warung, and it is only an option for those people who have a weekly or monthly income. Because it involves shopping, this is an option most commonly used by women, with the husband's wage often functioning as collateral. Usually women take out these loans because available shopping money is insufficient to meet the demands of the household. Later, the loan will have to be repaid with shopping money as well, an eventuality that could create another shortage so that it becomes necessary to buy on credit again. Women in the lower-income groups are most likely to become trapped in such a credit cycle. ${ }^{22}$

Pawnshops. The Indonesian government runs a network of pawnshops all over the country where a person can pawn valuable goods. These government shops are especially interested in gold, televisions, computers, and the like. The interest rate is

\footnotetext{
22 This is a good example of why the poor pay more. The need for shopping on credit forces poor housewives to shop in the ward instead of in the larger market, where prices are cheaper. At the same time, the owners of these neighborhood shops themselves are unable to charge interest or raise prices for those customers who want to buy on credit, so that the practice can threaten their businesses.
} 
set at around 3 percent per month. People who can afford to buy such luxury items often use them as assets which can be pawned to raise money to cover unexpected costs. The poor in Yogyakarta do not usually rely on official government pawnshops, however, unless they intend to pawn their gold. More often they go to the illegal pawnshops in Yogyakarta which are run by the Chinese. These shops charge a much higher interest rate than the government pawnshops (around 20 percent per month) and offer less money for the same article, but they do accept goods which the government pawnshops do not, such as clothes and household utensils. For this reason, they are more popular with the poor. If the pawnshop loan is not repaid within three months, the assets are sold.

Simpan pinjam. Finally there are mutual associations, the simpan pinjam, which provide credit. They are the Indonesian form of a type of association generally referred to as ASCRA (Accumulating Savings and Credit Associations). In an ASCRA, "the pooled savings are not instantly redistributed but kept in custody and allowed to accumulate by lending parts of the fund to members or outsiders for interest." 23 In Bujung, these institutions are predominantly the domain of men. The women in Bujung do participate in the simpan pinjam of the Family Welfare Program (PKK) ${ }^{24}$ in their own respective neighborhood sections, ${ }^{25}$ but the loans offered by these associations are often very small and economically meaningless. In the neighborhoods of the lower section of Bujung, it is common practice not to pay off the installments as they come due, but to wait a few months, then borrow from a friend or relative in order to repay the whole loan at once. A new loan from the association can then be acquired, which is used almost entirely to repay that friend or relative. The women themselves call this practice "speculation," as they speculate that the loan they will be able to acquire is bigger than the debt they have already incurred. The small "profit" they make can then be used to fill small holes in their shopping budgets. Most of these credit associations are PKK-sponsored groups that operate with government support, though a few associations have been initiated by private concerns. In these associations women from all levels of wealth participate, and a small number of women do take out comparatively large loans. Most tend to borrow as much as they can, pay their installments, and then borrow again as soon as possible, disregarding specific financial needs. ${ }^{26}$

${ }^{23}$ Frits J. A. Bouman, "ROSCA and ASCRA: Beyond the Financial Landscape," in Financial Landscapes Reconstructed: The Fine Art of Mapping Development, ed. Frits J. A. Bouman and Otto Hospes (Boulder, CO: Westview Press, 1994), p. 376.

${ }^{24}$ The Family Welfare Program, or Pembinaan Kesejahteraan Keluarga, is a government program in which each Indonesian mother is obliged to participate. In Bujung almost every woman attends the meetings in her own neighborhood section. A minority of the women participate in the PKK activities of the larger neighborhood, and only a few reach outside their own ward.

${ }^{25}$ The whole of Indonesia is officially subdivided along a variety of administrative lines, and the smallest segment is the neighborhood section, or Rukun Tetangga (RT). It consists of around forty families who reside close to each other. Bujung is made up of sixteen neighborhood sections.

${ }^{26}$ An interesting typology on the various sources of credit in Indonesia can be found in Frits J. A. Bouman and Henk A. J. Moll, "Informal Finance in Indonesia," in Informal Finance in Low-Income Countries, ed. Dale W. Adams and Delbert A. Fitchett (Boulder, CO: Wesview Press, 1992). 


\section{Negotiating over Different Kinds of Money}

Not all money is the same. Housewives tend to distinguish between different kinds of money on the basis of origin, destination, amount, and other similar considerations. ${ }^{27}$ Each housewife in Bujung has her own system for keeping track of cash flows in and around the household. For our analysis, it is useful to make a somewhat artificial distinction between three different kinds of money used for the household budget, defining each category according to which person is entitled to make decisions concerning that money.

Shopping money (uang belanja), which is used to cover the daily household expenses, is central to any household budget. This money is under the control of the wife, and only a few husbands keep a close eye on how she spends it. Apart from shopping money, there is pocket money (uang jajan), which individual members of the household can use for their own private purposes. Pocket money is available to husbands, children, and the elderly, while wives usually have to manage with their shopping money. The third category of money is stocked savings, money reserved for future expenditures. This money can be kept in a special jar in the house, at the bank, in an arisan, or in the form of durable goods. Deciding whether and when this money will be used is usually the joint responsibility of husband and wife. Their personalities largely determine which of them wields the most influence in such matters. In some households the money designated as shopping money may be insufficient, so that stocked savings or pocket money must regularly be spent to meet the pressing needs of the household. In other households, the shopping money may be more than sufficient, so that the wife is able to save part of it to meet future needs.

Even though the wife has the responsibility over the shopping money, the husband decides the actual quantity of funds to be earmarked as shopping money because it consists of the earnings of the wife plus whatever additional contribution is offered by the husband. Most husbands subtract a small amount from their own income before they give the money to their wives and use it for buying cigarettes, an occasional snack, and for gambling. A few "good" husbands simply give all of their income and ask for money every time they want to buy cigarettes. Their wives are often able to save relatively large amounts of shopping money, sometimes in secret jars, thereby expanding their own financial room to maneuver. The more common "tough" husbands make a conservative calculation of the shopping money their wives will need and keep the rest for themselves as pocket money. ${ }^{28}$ In these households, quarrels about money frequently erupt, and wives have to negotiate and cheat in order to meet expenses.

While men usually try to keep as much money for themselves as possible, women have a rather different objective in this negotiating process. Their goal is to improve their own ability to balance the household budget. This is what financial autonomy means to them. In practice, this means that they must seek funds to meet expenditures,

27 Viviana Zelizer, "The Special Meaning of Money: 'Special Monies,'” American Journal of Sociology 95,2 (1989): 342-77 already considered the existence of different kinds of money. She describes the special status of household money for housewives in the United States. She argues that "culture and social structure mark the quality of money by institutionalizing controls, restrictions, and distinctions in the source, uses, modes of allocation, and even the quantity of money. "Zelizer, "The Special Meaning of Money," p. 342.

28 The qualifications "good" and "tough" (baik and keras) were used by female informants. 
94 Hotze Lont

and that they must identify and select appropriate expenditures when money enters the house. Various considerations occupy women in Bujung as they attempt to balance the household budget and match income to expenditure: How do I make sure that I get enough shopping money? How do I make sure that we take in the right combination of small daily earnings and larger, less frequent, earnings? How do I make sure that I am not surprised by sudden high costs? How do I make sure that my husband does not spend too much on gambling and drinking? Balancing the household budget involves searching for an optimal or correct allocation of financial means over time. To achieve that balance, a woman has to deal with the demands of her husband and children, with the demands of her neighbors, her own desires as a consumer, and with unpredictable circumstances. For wives the basic objective, most of the time, is to enlarge their shopping budgets.

Negotiations between husbands and wives follow different paths. A woman can argue that she should have more shopping money, either because shopping costs are higher than estimated, or because her own income is lower than expected. For most men it is very difficult to check whether the financial picture presented by their wives is accurate or not, and this provides wives with an opportunity to manipulate the truth. Numerous women who have a hard time negotiating over shopping money consistently lie about the size of their own income, conceal their savings, and exaggerate household expenses. Many men, in turn, suspect that they cannot rely on their wives' reports, and therefore they try to restrict their contributions to a minimum or, like their wives, they lie about their own earnings. In such a situation of mutual distrust, wives have only one recourse: they must try to play on their husbands' sentiments. They can either act pitifully, by begging and whining, or angrily, by publicly denouncing their husbands as failures, unable to support the family. Other women choose to look for work if there is not enough money coming from their husbands. Many of them engage in home production or accept work as a maid, mainly because they want to have pocket money for themselves. Such independent action can have an adverse affect, however, since a husband might see that his wife is managing more comfortably and conclude that he can now allocate even less to the household and keep more for himself.

Women can also acquire supplemental resources by borrowing money. Women are generally free to borrow whatever they want in order to fill gaps in the shopping budget (although they have limited access to such loans), but they must also depend on that same shopping budget to repay these loans. If this becomes an ongoing structural problem, it can lead to spiraling debts, so that an increasing proportion of the shopping budget must be spent on installments and interest payments. However, we should remember that women's, as well as men's, incomes tend to fluctuate, so that women can count on eventual, occasional rezeki to escape mounting debts. ${ }^{29}$ One can imagine that accumulating debts might force husbands to make larger contributions to the household budget. If that were true, the practice of borrowing money could become

\footnotetext{
29 Repaying debts with debts is a financial strategy widely practiced in Bujung; in this way, people try to balance needs and rezeki over time. A more elaborate discussion can be found in Hotze Lont "When We are Broke . . . : Managing Unbalanced Cycles of Money in Urban Households, Yogyakarta, Indonesia," in Money and Culture: Examples from Indonesia, South-Africa and India, ed. Peer Smets, Urban Research Working Papers, No. 44 (Amsterdam: Free University, 1999).
} 
an instrument for women to use in their negotiations with their husbands. My research, however, did not turn up evidence that this strategy was being adopted by women.

When it happens that the wife wishes to take out bigger loans of the sort that often require collateral held by her husband, loans that cannot be easily repaid with the usual shopping budget, she needs the consent of her husband. Such debts will probably require that the household dip into its stocked savings, and, as noted above, husband and wife jointly control these savings. Thus a husband's inclinations would largely determine whether a woman could negotiate a large loan successfully.

\section{Household Management Practices Compared}

Though it must be acknowledged that the financial strategies of women in Bujung differ from person to person, significant patterns do distinguish the strategies of women who live in the upper section of the ward from the strategies of women who reside in the lower section. These can be illustrated through the cases of Yani and Gunem and their families, who represent typical examples of both social categories.

Yani and Sartono. Yani is the daughter of a civil servant from Bantul. In the 1980s she married Sartono who is the son of a civil servant from Madiun. While Sartono pursued his education in Yogyakarta, his father bought a small house for Sartono and his brother in the upper section of Bujung. After their marriage, Sartono's brother moved out, and Yani came to stay with her husband. Now the couple has three children, one in junior high school and two in primary school. Sartono works at the provincial labor department as an instructor, and he earns Rp450,000 per month. ${ }^{30}$ From July to October he can usually make some extra money when there are special projects at his workplace, but since the nation's economic crisis, this source of extra income has dried up. In the evenings, Sartono works odd jobs for acquaintances who hire him to paint their cars or motorcycles. Sartono hopes that after his retirement he can open a repair shop for cars. A few years ago Sartono borrowed money from his office co-operative so that Yani could open a small shop at their house. The shop was not a success, and they eventually abandoned the idea. They subsequently borrowed again from Yani's sister and from another source (probably a moneylender), this time for funds to purchase supplies so that they could make snacks and sell them at the market. Each time Sartono receives his wage, he brings it to the bank, and whenever the shopping money of his wife is depleted, they withdraw money from their bank account. Lately, the bank account has often been empty, and they have chosen to take out interim loans from the office co-operative or from the bank, where Sartono is qualified to borrow without putting up collateral. However, they must take care because the installment payments for such loans are automatically deducted from Sartono's wages, so that Sartono's monthly income has dwindled. The loans taken out by Sartono and Yani are relatively large. The couple makes decisions concerning their household loans and debts jointly.

Not all the women residents of the upper section of the ward are in a position like Yani's. Many participate in more simpan pinjam and manage their working capital

30 In July 1999, the date on which these amounts were established, the exchange rate was roughly Rp6,000 against one US dollar. 
independently. Other women have no idea how much their husbands earn and simply take whatever shopping money they are offered. Wanti, the wife of a civil servant, says:

In the households in this neighborhood it is the wife who knows what is going on with the money. When there is a need for money, it is the wife who looks for a loan. Today I took out a loan, and I am certainly not going to tell my husband because he will be angry with me. I am forced to borrow because the money he gives me is not enough. He says: "Here is the money, it is up to you." I just have to manage with what he gives. On the other hand, he also has secrets from me. I saw on his payroll that he himself took a loan from the office. I asked him what it was for, and he answered that it was for some necessity. Well, what can I do about that!?

Nevertheless, women like Wanti remain an exception in the upper-class section.

Gunem and Slamet. Gunem is the daughter of a landless peasant from Gunung Kidul. Her husband, Slamet, was born in Gunung Kidul as well. He came to Yogyakarta to work as a pedicab driver, but he gradually became a construction worker who specialized in digging wells. Now they live in the lower section of Bujung with three of their four children, the husband of their oldest daughter, and a grandchild. Slamet can only dig wells in the dry season, but when he has a job, Slamet can make Rp100,000 in three days. In construction, he can earn Rp10,000 per day. The wage is respectable, but the work is irregular; he can be without a job for many days. Gunem herself has found a job as a housemaid for a Chinese family; she receives a basic income of $R p 120,000$ per month. She occasionally receives extra money for odd jobs, and her employers pay special bonuses for the religious holidays. The couple's two oldest children have already found paid work, but they spend their earnings as they please and only contribute to the household budget whenever there is a shortfall. Slamet and Gunem regularly borrow money from a variety of sources, including moneylenders, simpan pinjam, neighbors, Gunem's boss and colleagues, and the pawnshop. Usually they must resort to such loans because Slamet has failed to find work, or because unexpected costs, such as school fees or expenses for their daughter's wedding, have cropped up. But even payments for daily food often exceed Gunem's fund of shopping money. Gunem herself says that she cannot always rely on her husband.

Slamet often does not have a job, and when he does have a job he just gives me so and so much money. That is not enough to take care of the family, and therefore I went to work. Almost all the women in this part of the neighborhood work because they cannot manage with what their husbands give them. If I can, I try to keep some money apart. If Slamet has a good job I can bring some money to the bank, or I buy some gold. Each month I save money with my boss, so that not all that I earn is spent on food. Slamet does not know. He thinks I only earn Rp75,000.

Even though she has some savings put away, Gunem prefers to borrow money when she is out of shopping money. "I want to keep these savings as long as possible."

In the lower section of Bujung, not every woman finds herself in Gunem's situation, of course. Some women never borrow and always discuss financial problems openly 
with their husbands. Other women trust their husbands even less than Gunem does and are forced to keep secret savings. There is the case of Giyem, wife of an oftenunemployed electrician, for example. Before the economic crisis, Giyem used to have three different places to save money, one box for shopping money, one for business capital, and one where she put away money to pay for the circumcision of her son. She kept these last two boxes hidden, and her husband did not even know that the third existed. Eventually when the son needed to be circumcised, her husband came to Giyem to discuss the problem: "Maybe we should borrow some money." Then she presented the box to him, saying: "See, I have saved some money." Giyem explained:

I kept it a secret because otherwise it may happen that he wants to buy cigarettes, and he does not have the money. He might easily take from that savings box. Or he is alone and wants to watch TV. He asks me whether I have any money to buy cigarettes. I say: No, there is no money, you will have to do without. Of course he could be very angry when it turns out that there has been money all the time, but he will not. He has been lied to, but it was a good lie. In the end he is also happy that we do not have to borrow.

Another woman called Tatik told me that she did not have a secret box, but "if I had a husband who liked to gamble and hang around [as Giyem's husband does], I would probably have a secret box too."

When it comes to access to credit, certain differences between people residing in the upper and the lower sections of the ward play crucial roles. People in the upper section of Bujung generally have higher and more stable incomes than those in the lower section. Because people living in the upper section are more likely to own their own houses and land, they tend to be more eligible for bank loans. What's more, securing those loans is a relatively simple process, since their job contracts often function as collateral. But the risk of losing their assets scares many people away from this option.

Though we note that people of this higher class generally have an easier time securing loans, it is also true that women living in the upper section have less access to credit than do women living in the lower section, since poorer women enjoy greater access to roving moneylenders and neighbors. Daily interaction between neighbors is a lot less frequent in the upper section of the ward, and inhabitants are generally less concerned and knowledgeable about each other's financial affairs. Because of this, loans from neighbors are rarely sought or offered. Moneylenders are also a comparatively rare sight in the upper section, and because so few people in this area resort to moneylenders, those who do are more likely to attract scorn from their neighbors. Of course, inhabitants of the upper section have less need for such loans, since they are more financially secure in many ways; most of them have health insurance, for instance, and some are enrolled in education savings plans. Furthermore, inhabitants of the upper section can rely more confidently on support from their relatives. This is the case not only because wealthier people tend to have wealthier relatives, but because the borrowers' basic income makes them more likely to repay the debt and reciprocate the loan at some time in the future. Families in the upper section enjoy more financial security than the poor, as we would expect. (This does not mean they often accumulate surplus income, since their higher expenditures for luxury items, education, and travel usually consume any surplus.) But again, because the sources of credit generally available to, and tolerated by, such families are more likely to be 
connected to the office than to the street, these comparatively affluent women themselves have rather limited access to credit. ${ }^{31}$

Women living in the upper section earn substantially less than their husbands do. They generally engage in trading, sewing, and sometimes in home production, while their husbands earn a salary at the office. Their income is considered to be a small but welcome addition to the basic income earned by their husbands. And yet these women, who do not earn a large proportion of the household income, seem to exercise considerable control over the household budget, not only with respect to the shopping money but also to the stocked savings. They seldom venture out to borrow money, because their husbands have better sources of credit at their disposal, but they certainly do influence the way that money is spent.

In comparison, the women residents of the lower-class section often earn nearly as much as, if not more than, their husbands do. Their stable incomes as maids and laundry women form the basis for the household budget, while the unreliable incomes that their husbands earn as pedicab drivers or construction workers figure as welcome additions to the household funds. Yet although most of these women earn a relatively large part of the household income-in some cases more than half-they exercise comparatively less control over the money earned by their husbands than is true for the more affluent women. Their husbands seem to think that since these wives earn money, they can take care of themselves. What's more, because incomes in this part of the neighborhood tend to be lower and more unreliable, husbands struggle more fiercely for their share of the money. Poorer wives engage in more frequent and more intense open conflicts about money with their husbands. And when it becomes necessary to take out a loan, it is usually these women who venture to find a lender, since like wealthier women they are anchored to the home, but, unlike them, they have ready access to sources of credit-moneylenders, neighbors-easily reached from the home. Do these conditions show the women to be powerful or powerless, autonomous or dependent? I would argue that potential answers to these questions are not so neatly opposed as many have assumed. Female "self-reliance" and economic insecurity appear to be closely interlinked.

\section{Conclusion}

The social and cultural factors which social anthropologists have cited to explain the strong position of Southeast Asian women in the household are certainly at work in Bujung. Women of the upper and lower classes control the shopping budget, while stocked savings are managed by husband and wife together. However, financial autonomy is not only a matter of having the right to decide how money will be spent. Autonomy will vary depending on the amount of money available to be spent. The relative sizes of both budgets, and thus the financial autonomy of the respective wives, are determined in each case by how much the husband is willing to contribute. If the husband is willing to contribute a great deal, then the wife has sufficient financial

\footnotetext{
31 Regarding consumption, it is clear that women in both categories spend considerably less on personal consumption than their husbands do. Men living in the lower section spend considerable amounts of money on drinking, gambling, and smoking. Men living in the upper-class section are more likely to make purchases that contribute to the entire household, but these will be luxury purchases, like televisions sets, or even additions to the house.
} 
space to determine how much money she wants to set aside for shopping and how much she wants to save. If the husband is not willing, or simply unable, to contribute enough, then the wife faces financial problems. Men ultimately decide on the actual size of the shopping budget by rationing their contributions.

To be more clear, female financial autonomy does not mean that a woman can spend money for herself. In Java, women are strongly influenced by social norms that expect them to consider the needs of other household members first, before thinking about their own. Wives are less comparatively concerned with their own consumer needs. My research showed that they were primarily concerned with providing food for their families, avoiding embarrassing scenes with screaming children, and complying with reciprocal payments to neighbors, friends, and relatives. Their financial autonomy lies in their ability to make these expenditures according to their own wishes and insights.

Husbands (and children) are not interested at all in the financial matters of the household. They just want to make sure that there is enough money to fulfill their personal needs, to buy cigarettes, to go gambling, and to buy the things they want to buy. Husbands generally do not contest their wives' authority over the shopping budget; rather, it is the size of the shopping budget that is subject to discussion. The fact that these different members of the household have different objectives often leads to domestic conflicts concerning money. The less money there is available, the fiercer the struggle. Women have limited ability to negotiate, especially because they depend in part on the income of their husbands.

The incident involving Parman and his wife, described at the beginning of this essay, shows how little control many wives from the lower section of Bujung have over the size of their shopping budgets. They are forced to accept that their husbands may bring home something one day and nothing the next. After he makes some money, Parman thinks first about himself and then about his family. Partly as a consequence of her husband's habits, his wife finds it hard to fulfill the "household needs," let alone to satisfy her own desires for consumer goods. Given the situation, her only recourse is to shame him in front of a guest. This makes Parman feel, at least, a bit uneasy, but I am afraid that it has not kept him from doing the same thing again.

At last, financial autonomy appears to be related most strongly to the total household income and not so much, as is often suggested, to the relative contribution of the wife. Despite the fact that women living in the lower section of the ward make relatively larger contributions to the household and have greater access to credit, these comparatively poor women enjoy less financial autonomy than do women in the upper section. The latter can exercise a similar form of control, but they control a larger (shopping) budget, which means they have more financial autonomy. In other words, I conclude that when women come to earn a relatively smaller part of an expanding household income, this may in fact increase their financial autonomy.

These observations also suggest that access to credit does not substantially contribute to female financial autonomy. If a woman uses loans to supplement her shopping budget, which is most often the case in Bujung, this means little for her financial autonomy because eventually she also has to break into that same budget to repay the loan. At best, the loan allows her the ability to manage her shopping money 
100 Hotze Lont

in a more flexible way. Contrary to the hopes and suggestions of many microfinance institutions, women rarely use loans to invest in business. Even if they did, it would contribute little to their financial autonomy. An expansion of her enterprise would increase a woman's workload, and it might very well cause her husband to ration his contribution to the household even more strictly, especially in low-income households where money is scarce. 